\title{
PERLINDUNGAN HUKUM MEREK TERKENAL TERKAIT DENGAN PERSAINGAN USAHA TIDAK SEHAT
}

\author{
A.A. Ngurah Bagus Bayu Prasetia, I Nyoman Putu Budiartha, Ni Made Puspa Sutari Ujianti \\ Fakultas Hukum Universitas Warmadewa, Denpasar - Bali, Indonesia
}

\begin{abstract}
Abstrak
Dengan perkembangan jaman saat ini banyak sekali merek terkenal yang beredar di pasar di Indonesia khususnya merek yang secara sengaja di palsukan oleh para pelaku usaha melanggar aturan yang ada di Indonesia demi mencari keuntungan. Peredaran merek terkenal yang banyak dipalsukan telah menyebar ke dalam lapisan masyarakat. Dengan adanya berbagai macam merek terkenal, munculah dampak negatif yakni adanya pelanggaran merek merupakan wujud persaingan usaha tidak sehat. Penelitian ini mengkaji pengaturan merek terkenal di Indonesia dan perlindungan hukum terhadap merek terkenal dikaitkan persaingan usaha tidak sehat di Indonesia. Untuk mencapai tujuan ini, kajian ini dilakukan menggunakan metode penelitian hukum normatif. Pada mulanya pengaturan merek terkenal diatur di dalam Paris Convention for the Protection of Industrial Property (Paris Convention) dan the Agreement on Trade-Related Aspects of Intellectual Property Rights (TRIPS Agreement). Pada saat ini Indonesia telah membuat aturan tersendiri mengenai Merek Terkenal dan yang terbaru Peraturan mengenai merek terkenal diatur di dalam Undangundang Nomor 20 Tahun 2016 tentang Merek dan Indikasi Geografis. Perlindungan hukum preventif bertujuan untuk memberikan payung hukum kepada para pengusaha yang mempunyai merek terkenal untuk menantisipasi terjadinya pelanggaran. Perlindungan hukum represif memberikan payung hukum terakhir pemberian sanksi kepada pelaku usaha yang sengaja menjiplak merek terkenal yang telah terdaftar di Indonesia. Upaya hukum perdata maupun pidana diberikan apabila sengketa sudah terjadi atau suatu pelanggaran telah dilakukan. Hendaknya pemerintah perlu mengadakan sosialisasi mengenai bentuk-bentuk pelanggaran. Pelaku usaha hendaknya lebih kreatif dan lebih mengiklankan mereknya sendiri supaya masyarakat mendapatkan informasi yang jelas mengenai merek terkenal yang asli maupun yang paslu.
\end{abstract}

Kata Kunci: Merek Terkenal; Perlindungan Hukum; Persaingan Usaha Tidak Sehat

\begin{abstract}
With the current development, there are many well-known brands circulating in the market all over Indonesia, especially the ones that are deliberately counterfeited by business actors violating existing regulations for profit. The circulation of a well-known brand that is widely fabricated has spread to all levels of society. With the existence of various well-known brands, there will be a negative impact, such as the emergence of brand violations which is a form of unfair business competition. This study examines the regulation towards the wellknown brands in Indonesia and the legal protection for well-known brands in relation to unfair business competition in Indonesia. To achieve these goals, this study was conducted using normative legal research method. Initially, the regulation of the famous brands is regulated in the Paris Convention for the Protection of Industrial Property (Paris Convention) and the Agreement on Trade-Related Aspects of Intellectual Property Rights (TRIPS Agreement). At this time, Indonesia has made its own regulations regarding Famous Marks and most recently the Regulations regarding famous marks are regulated in Law Number 20 of 2016 concerning Trademarks and Geographical Indications. Preventive legal protection aims to provide a legal umbrella for entrepreneurs who have well-known brands to anticipate violations. Repressive legal protection provides the final legal umbrella for imposing sanctions on business actors who deliberately copy the famous brands that have been registered in Indonesia. Civil and criminal remedies are given when a dispute has occurred or a violation has been committed. The government should conduct socialization regarding the forms of violations. Entrepreneurs should be more creative and advertise their own brands more so that people can get clear information about well-known brands, both genuine and the counterfeited.
\end{abstract}

Keywords: Famous Brands; Legal protection; Unfair competition 


\section{PENDAHULUAN}

Dewasa ini perekonomian dan perkembangannya perlu diatur dan dilakukan pengendalian terhadap hukum agar tidak ada lagi pelanggaran aturan yang ada di Indonesia. Pengaturan hukum terhadap perekonomian harus dikendalikan supaya tidak ada penyimpangan dari cita-cita pembangunan bangsa ini. Hukum atau aturan diciptakan agar masyarakat tetap dalam aturan atau koridor hukum yang diatur. Pada hakikatnya aturan hukum di bidang perdagangan dan perekonomian belum sepenuhnya mengatur mengenai hal ini (Ardian, 2008). Sementara aturan hukum yang selalu berubah-ubah menyesuaikan dengan kondisi saat ini.

Kenyataan dewasa ini merek adalah elemen penting dari kekayaan intelektual, yang terlahir dari ide atau pikiran manusia itu sendiri (Sufiarina, 2019). Merek pada dasarnya melekat pada barang ataupun jasa. Merek sebagai bentuk strategi dalam dunia usaha, semakin terkenal merek itu semakin banyak pula peminatnya di masyarakat serta meningkatnya produksi dari barang maupun jasa merek tersebut. Ini adalah cerminan dari peningkatan ekonomi yang tumbuh di tatanan kehidupan dalam bermasyarakat.

Merek terkenal adalah merek yang sangat indah, bersinar dan pada saat dilihat setiap orang ingin menggunakan dan memiliki suatu produk yang dihasilkan oleh merek serta apabila dipakai langsung menjustifikasi bahwa) pemakai merek tersebut sudah dipastikan dari kalangan menengah keatas ataupun para sosilaita (Riswandi, 2006: 78). Merek terkenal pada dasarnya adalah merek yang sudah melekat didalam produk yang diperjual belikan secara resmi di Indonesia. Kebanyakan merek terkenal sudah dikonsumsi oleh masyarkat luas. Suatu merek terkenal sudah menjadi kebutuhan pokok bagi masyarakat kalangan menengah keatas.

Para pelaku usaha dalam membuat produk hingga menjadi merek dan dikenal oleh masyarkat luas sudah sepatutnya mendaftarkan suatu merek dari barang atau jasa yang diperjual-belikan (Darusman, 2016). Hal ini seperti yang sudah diamanatkan dalam Undang-undang Nomor 20 Tahun 2016 tentang merek dan indikasi geografis pada Pasal 3. Apabila merek telah didaftarkan maka akan mendapatkan pengakuan dari Negara dan mendapakan sertifikasi terhadap merek yang telah didaftarkan.

Tujuan utama dari pendaftaran merek itu untuk mendapatkan pengakuan hukum sehingga tidak ada yang memalsukan. Namun dalam kenyataannya di masyarakat terdapat banyak sekali merek terkenal yang dipaslukan dan diperjual belikan di tengah masyarakat Indonesia. Dari penjelasan terbut permasalahan dalam penelitian ini adalah: 1) Bagaimana pengaturan merek terkenal di Indonesia? 2) Bagaimana upaya perlindungan hukum terhadap merek terkenal terkait dengan persaingan usaha tidak sehat di Indonesia. Penelitian ini dilakukan untuk mengungkap pengaturan merek terkenal di Indonesia. dan untuk mengetahui apakah hukum telah mengakomodasi merek terkenal supaya tidak ada lagi tangan-tangan jahil yang ingin mencari keuntungan dengan cara melanggar aturan yang diberlakukan di Indonesia sehingga dapat merugikan pelaku usaha maupun masyarakat pengguna produk merek terkenal.

Selain menjadi bagian dari informasi atau sosialisasi kepada masyarakat untuk dapat memehamai aturan hukum dan persaingan usaha yang tidak sehat, penelitian ini juga menyajikan ide dan memberikan pemahaman dalam bidang ilmu hukum, khususnya dalam hal merek terkenal dan bisa dijadikan rujukan bagi para penggiat ilmu hukum di Indonesia terkait dengan perlindungan hukum merek terkenal di Indonesia.

Terkait dengan merek, penelitian ini mengkaji dua isu hukum, yaitu pengaturan merek terkenal di Indonesia dan perlindungan hukum terhadap merek terkenal dikaitkan persaingan usaha tidak sehat di Indonesia.

\section{METODE PENELITIAN}

Dalam penelitian ini penulis menggunakan tipe penelitian hukum normatif. Penelitian hukum normatif adalah penelitian hukum yang mengkaji hukum tertulis dari berbagai aspek, yaitu aspek teori, sejarah, filosofis, perbandingan, struktur dan komposisi, lingkup dan materi konsistensi penjelasan umum dan pasal demi pasal, formalitas dan mengikat suatu undang-undang, serta bahasa hukum yang digunakan. Sesuai dengan penelitian hukum yang digunakan yaitu pendekatan penelitian hukum normatif, pendekatan masalah yang digunakan adalah dasar pendekatan konseptual dan perundang-undangan. 
Dalam penelitian ini digunakan pendekatan Perundang-undangan (the statute approach) dan pendekatan Konseptual (conceptual approach). Pendekatan Perundang-undangan adalah pendekatan yang dilakukan berbagai aturan hukum yang berkaitan dengan perlindungan merek dan persaingan usaha tidak sehat. Pendekatan konseptual adalah pendekatan yang beranjak dari pandanganpandangan dan doktrin-doktrin yang berkembang di dalam ilmu hukum. Pendekatan ini menjadi penting sebab pemahaman terhadap pandangan atau doktrin yang berkembang dalam ilmu hukum dapat menjadi pijakan untuk membangun argumentasi hukum ketika menyelesaikan isu hukum yang dihadapi. Pandangan atau doktrin akan memperjelas ide-ide dengan memberikan pengertianpengertian hukum, konsep hukum, maupun asas hukum yang relevan dengan permasalahan.

Bahan hukum primer yang merupakan bahan hukum pokok dalam penelitian ini. Bahan hukum primer adalah bahan pustaka yang mencakup peraturan perundang-undangan, buku-buku kepustakaan, karya ilmiah, artikelartikel, serta dokumen-dokumen yang berkaitan dengan materi penelitian. Adapun peraturan perundang-undangan yang berkaitan dengan penelitian ini adalah Undang-Undang Nomor 20 Tahun 2016 tentang Merek dan Indikasi Geografis, Undang-Undang Nomor 5 Tahun 1999 tentang Larangan Praktek Monopoli dan Persaingan Usaha Tidak Sehat. Bahan hukum sekunder yang memberikan penjelasan mengenai bahan hukum primer, seperti misalnya hasil penelitian, hasil karya ilmiah para sarjana, artikel, file elektronik, website, buku- buku yang berhubungan dengan pokok permasalahan dalam penelitian ini. Bahan hukum tersier, yaitu bahan yang memberikan petunjuk maupun penjelasan terhadap bahan hukum primer dan sekunder, contohnya adalah kamus hukum, kamus besar bahasa Indonesia, kamus bahasa Inggris, kamus bahasa Belanda, dan lain sebagainya.

Bahan hukum dikumpulkan melalui prosedur inventarisasi dan identifikasi peraturan perundangundangan, serta klasifikasi dan sistematisasi bahan hukum sesuai permasalahan penelitian. Oleh karena itu, teknik pengumpulan data yang digunakan dalam penelitian ini adalah dengan studi kepustakaan dan studi dokumen. Studi pustaka adalah pengkajian informasi tertulis mengenai hukum yang berasal dari berbagai sumber dan dipublikasikan secara luas serta dibutuhkan dalam penelitian hukum normatif. Studi dokumen merupakan pengkajian informasi tertulis mengenai hukum yang tidak dipublikasikan secara umum, tetapi dapat diketahui oleh pihak tertentu. Pengkajian dan analisis informasi tertulis mengenai hukum yang tidak dipublikasikan secara umum berupa dokumen yang berkaitan dengan pokok bahasan penelitian ini.

Berdasarkan jenis bahan hukum yang diperoleh, penelitian menggungunakan metode deduktif dalam menganalisis data, yaitu metode menganalisis peraturan perundang-undangan sebagai hal umum, kemudian ditarik simpulan yang bersifat khusus. Selanjutnya dibahas, disusun, diuraikan dengan teknik inteprstasi, serta dikaji permasalahan sehingga di peroleh suatu kesimpulan upaya pemecah masalah.

\section{HASIL DAN PEMBAHASAN}

\section{Pengaturan Merek Terkenal di Indonesia}

Merek biasanya berbentuk gambar atau nama untuk tujuan pemasaran dan menggaet konsumen agar menggunakan produknya. Pelaku usaha yang sadar aturan hukum akan mendaftarkan suatu produknya untuk mendapatkan kepastian hukum dari merek yang akan dipasarkannya yang berfungsi sebagai branding ataupun promosi. Para pebisnis biasanya mendaftarkan merek untuk mencegah pihak lain menggunakan merek tersebut dan mencegah terjadinya pemalsuan suatu produk yang dihasilkan dari merek tersebut. Sudah pasti semua usaha dan aturan yang dilakukan membutuhkan waktu, tenaga dan uang sebagai pengorbananya (Prakoso, 1987: 42).

Penjelasan mengenai merek sebagaimana yang tertuang di dalam Pasal 1 Angka 1 UndangUndang Nomor 20 Tahun 2016 tentang Merek dan Indikasi Geografis, menentukan bahwa:

"Merek adalah tanda yang dapat ditampilkan secara grafis berupa gambar, logo, nama, kata, huruf, angka, susunan warna, dalam bentuk 2 (dua) dimensi dan/atau 3 (tiga) dimensi, suara, hologram, atau kombinasi dari 2 (dua) atau lebih unsur tersebut untuk membedakan barang dan/atau jasa yang diproduksi oleh orang atau badan hukum dalam kegiatan perdagangan barang dan/atau jasa."

Merek merupakan ujung tombak perdagangan barang dan jasa. Sejalan dengan hal tersebut para pengusaha menggunakan merek untuk selalu menjaga kualitas yang terbaik dari sebuah produk yang dikeluarkan baik itu barang maupun jasa yang diedarkan dipasaran. Barang maupun jasa yang 
dihasilkan sudah tentu untuk mencegah pihak lain dalam persaingan usaha yang tidak sehat yang secara sengaca mencatut suatu brand merek terkenal untuk menguntungkan diri sendiri dengan cara menjiplak ataupun memalsukan merek tersebut. Merek sebagai sarana pemasaran dan periklanan $(a$ marketing and advertising device) memberikan suatu tingkatan informasi tertentu kepada konsumen mengenai barang dan/atau jasa yang dihasilkan pengusaha. (Jened, 2007: 160-161).

Dalam hukum merek, merek dibagi menjadi 2 yaitu merek dagang dan merek jasa sebagaimana yang diatur didalam Pasal 2 ayat (2) Undang-undang merek adalah sebagai berikut:

a. Merek Dagang adalah merek yang digunakan pada suatu produk yang diperjualbelikan di masyarakat oleh pelaku usaha dan digunakan sebagai kebutuhan dalam menunjang aktifitas maupun gaya hidup, biasanya merek dagang disini merek yang sudah terkenal dan identik dengan barang mewah dan mahal;

b. Merek Jasa adalah merek yang bergerak di bidang jasa ataupun layanan di masyarakat selain merek dagang ataupun produk barang. Merek jasa berfungsi sebagi pembeda dari jasa-jasa lainnya yang berada ditengah-tengah masyarakat.

Menurut Arie Siswanto, yang dimaksud dengan hukum persaingan usaha (competition law) adalah instrumen hukum yang menentukan tentang bagaimana persaingan itu harus dilakukan. (Hermansyah, 2008: 1). Persaingan usaha pada prinsipnya harus sehat namun dalam kenyataannya persaingan usaha tidak sehat banyak terjadi dimasyarakat saat ini. Mereka mencari keuntungan dari hasil melakukan pelanggaran hukum yakni dengan memalsukan produk, meniru, menjiplak dan menjual secara illegal tanpa melewati prosedur yang berlaku. Dengan adanya persaingan usaha tidak sehat ini yang sangat dirugikan dan merasakan dampaknya adalah msyarakat itu sendiri.

\section{Perlindungan Hukum terhadap Merek Terkenal}

Perlindungan hukum sudah sepatutnya mengayomi masyarakat yang dirugikan terhadap persaingan usaha tidak sehat, tujuan dari perlindungan tersebut bermanfaat untuk masyarakat supaya dapat menggunakan produk- produk yang bermanfaat dan sesuai aturan yang berlaku. Pada prinsipnya perlindungan hukum sebagai langkah hukum yang diberikan oleh Negara yang bertujuan memberikan rasa keadilan, baik secara intelektual maupun gangguan dari pihak lain yang ingin menggunakan merek dimaksud untuk kepentingan yang tidak baik bahkan merugikan pelaku usaha maupun masyarakat (Rahardjo, 2000: 74).

Perlindungan hukum sebagai tindakan perventif maupun represif dari perilaku yang kurang baik serta melindungi dari penguasa yang semena-mena dengan tidak menjalankan aturan hukum yang dibuat dan berlaku di Indonesia, yang mana seharusnya penguasa harus memberikan perlindungan untuk menjaga ketertiban, kenyamanan, ketentraman bagi pelaku usaha maupun masyarakat yang menggunakan produk merek tersebut dengan tujuan untuk dapat digunakan dan dinikmati produk yang dibelinya oleh masyarakat itu sendiri (Setiono, 2004: 3).

Di dalam aturan hukum yang berlaku di Indonesia, perlindungan hukum dibagi menjadi 2, yaitu (Ishaq, 2009: 43):

a. Perlindungan Hukum Preventif adalah upaya perlindungan yang diberikan oleh penguasa yang bertujuan mencegah terjadinya suatu pelanggaran. Sebagaimana yang terdapat dan diatur dalam peraturan perundang-undangan yang berlaku di Indonesia dengan tujuan mencegah terjadinya sesuatu hal yang sangat merugikan pelaku usaha pemengang merek yang telah didaftarkan.

b. Perlindungan Hukum Represif adalah upaya hukum terakhir apabila terjadi pelanggaran sesuai dengan tata cara dan aturan yang diatur dalam peraturan perundang-undangan apapbila terjadi sengketa bisa digugat baik secara pidana maupun perdata.

Kepastian hukum dalam hukum positif di Indonesia harus memberikan rasa keadilan bagi semua kalangan dengan tujuan masyarakat mendapatkan keamanan dan kenyamanan. Keamanan dan kedamaian harus dibangun sesuai dengan cita-cita hukum yang telah diatur dalam bernegara, bukan Negara yang mau seenaknya sendiri tanpa memikirkan rasa aman, nyaman dan tentram bagi seluruh masyarakat. Dalam penegakkan hukum yang memiliki rasa keadilan harus memperhatikan 4 unsur (Ishaq, 2009: 43):

1) Kepastian hukum (Rechtssicherkeit)

2) Kemanfaat hukum (Zeweckmassigkeit)

3) Keadilan hukum (Gerechtigkeit) 
4) Jaminan hukum (Doelmatigkeit).

Hukum dalam memberikan perlindungan dapat melalui cara-cara tertentu, antara lain yaitu dengan (Sasongko, 2007: 31):

1. Membuat peraturan (by giving regulation), bertujuan untuk:

a. memberikan hak dan kewajiban baik itu masyarakat sebagai pengguna merek maupun para pelaku usaha yang ingin produknya laku terjual;

b. menjamin rasa keadilan dan manfaat yang didapat terhadap suatu produk;

2. Menegakan peraturan (by law enforcement) melalui:

a. administrasi negara seperti melakukan persyaratan yang sangat ketat dalam mengeluarkan perijinan dan melakukan pengawasan langsung kepada pelaku usaha serta meninjau langsung pembuatan produk-produk yang akan dipasarkan sudah layak dan aman dikonsumsi oleh masyarakat luas apabila melanggar pesyaratan bisa langsung ditindak tegas dengan cara mencabut semua perijinan usaha yang dimiliki;

b. hukum pidana yang berfungsi memberikan efek jera bagi oknum-oknum yang merugikan masyarakat serta pemerintah dengan melanggar aturan pidana yang berlaku dengan memberikan sanksi pidana;

c. hukum perdata yang berfungsi sebagai perlindungan hak-hak kepada pihak yang dirugikan serta menuntut ganti rugi yang sepadan karena telah merugikan usahanya.

Keadilan dimasyarakat belum seluruhnya dapat dirasakan karena masih adanya kepentingan dari pemangku jabatan yang lebih mengutamakan dirinya sendiri maupun golongannya. Tentu saja hal tersbut sangat menyakiti perasaan masyarakat, terlebih lagi dalam hal-hal tertentu terkesan masyarakat dipaksa harus menggunakan produk-produk yang pada dasarnya tidak dibutuhkan oleh masyarakat atau masyarakat tidak mau menggunakan produk dimaksud melainkan ingin membeli merek lain sesuai kebutuhan dan kemampuannya.

Rasa keadilan di masyarakat bisa tercapai apabila aturan hukum yang berlaku di Indonesia memiliki sifat mengayomi, memberikan rasa aman dan memberikan keadilan yang berpihak kepada masyarakat, hal ini tercermin dalam aturan hukum yang dibuat oleh Penguasa bersifat preventif maupun Represif. Adapun perlindungan preventif sebagai tameng sebelum terjadi suatu kejahatan maupun pelanggaran sedangkan perlindungan represif sebagai jalan terakhir apabila terjadi suatu pelanggaran sehingga penyelesaianya di lembaga Peradilan.

\section{SIMPULAN DAN SARAN}

\section{Simpulan}

Aturan merek terkenal secara eksplisit mengenai pengertian merek terkenal belum dijelaskan secara gamblang di Indonesia diatur dalam Undang-undang Nomor 20 Tahun 2016 tentang merek dan indikasi geografis namun secara implisit merek terkenal ada dalam Undang-undang merek. Perlindungan hukum terhadap pemilik hak merek terdaftar dari upaya tangan-tangan jahil yang ingin menguntungkan diri sendiri dengan menjiplak atau memalsukan merek barang maupun jasa dengan cara melakukan pendaftaran merek pada Dirjen Haki yang sudah ditentukan agar mendapatkan sertifikasi dan tidak ada kemiripan dengan merek yang telah terdaftar. Upaya hukum yang dapat ditempuh terhadap pelanggaran yakni dengan cara mencabut ijin usaha dan memberikan ganti rugi bagi korban serta melaporkan agar bisa ditindak sesuai hukum pidana.

\section{Saran}

a. Bagi Pemerintah

Pemerintah seyogyanya perlu mengadakan sosialisasi apa saja yang menjadi bentuk pelanggaran serta aturan hukumnya dan yang sengaja melanggar aturan hukumnya agar segera ditindak dan disebarluaskan kepada masyarakat sehingga masyarakat mengetahui bahwa produk itu illegal ataupun palsu. Pemerintah melalui lembaga yang berwenang sudah sepatutnya memberikan persyaratan yang sangat ketat dan melakukan pengawasan terhadap pendaftaran merek dimaksud supaya tidak ada lagi yang merasa dirugikan terhadap pendaftaran merek itu sendiri, karena selama ini terlalu banyak juga yang bermain demi kepentingan sendiri tanpa memperdulikan kerugian yang diderita oleh orang lain.

b. Bagi Pelaku Usaha 
Untuk pelaku usaha penting untuk memperhatikan aturan hukum yang berlaku agar tidak ada lagi masyarakat yang dirugikan terhadap pelanggaran merek yang beredar dan di konsumsi oleh masyarakat, agar tidak ada lagi kecurangan dalam persaingan usaha tidak sehat dan tidak lagi memalsukan atau menjiplak merek terkenal yang dari segi kualitas jauh dari aslinya.

c. Bagi Masyarakat

Masyarakat agar lebih teliti dalam membeli dan menggunakan sebuah merek barang maupun jasa dapat memahami dan mengetahui perihal tentang keabsahan pendaftaran supaya tidak dirugikan dengan pemakaian merek yang beredar di Indonesia yang mana merek dimaksud dibuat dengan melanggar aturan hukum yang berlaku dan diidikasikan terdapat tindak pidana.

\section{DAFTAR PUSAKA}

Ardian, A. V. (2008). Prospek Perlindungan Hukum Hak Kekayaan Intelektual dalam Kesenian Tradisional di Indonesia. Universitas Diponegoro.

Darusman, Y. M. (2016). Kedudukan serta Perlindungan Hukum bagi Pemegang Hak Paten dalam

Kerangka Hukum Nasional Indonesia dan Hukum Internasional. Yustisia Jurnal Hukum, 5(1), 203-215.

Hermansyah. (2008). Pokok-Pokok Hukum Persaingan Usaha di Indonesia. Kencana.

Ishaq. (2009). Dasar-dasar Ilmu Hukum. Sinar Grafika.

Jened, R. (2007). Hak Kekayaan Intelektual Penyalahgunaan Hak Ekslusif. Airlangga University Press.

Prakoso, D. (1987). Perselisihan Hak atas Merek di Indonesia. Liberty.

Rahardjo, S. (2000). Ilmu Hukum (Cetakan Ke). PT. Citra Aditya Bakti.

Riswandi, B. A. (2006). Hukum Cyberspace (Cetakan Pe). Gitanagari.

Sasongko, W. (2007). Ketentuan-Ketentuan Pokok Hukum Perlindungan Konsumen. Universitas Lampung.

Setiono. (2004). Rule of Law (Supremasi Hukum). Universitas Sebelas Maret.

Sufiarina. (2019). Hak Prioritas dan Hak Ekslusif dalam Perlindungan HKI. ADIL: Jurnal Hukum, $3(2), 265-281$.

Undang-Undang Nomor 10 Tahun 2016 Tentang Merek dan Indikasi Geografis.

Undang-Undang Nomor 5 Tahun 1999 Tentang Larangan Praktek Monopoli dan Persaingan Usaha Tidak Sehat 